\title{
Total Phenolic, Total Flavonoid Content and in vitro Sun Protection Factor test of Arabica Coffee Leaves Extract (Coffea arabica L)
}

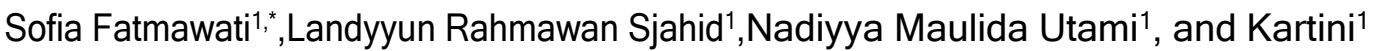

\begin{abstract}
Background: Arabica coffee leaf (Coffea arabica L.) is a well-known plant by the Indonesian people because it has many benefits apart from being a drink. Coffee leaves are known to have good antioxidant activity. The use of antioxidants in sunscreen preparations can prevent various diseases caused by UV radiation from UV rays' sunlight.

Aim: This study aims to determine the phenol content, the flavonoid content and the value of Sun Protection Factor (SPF) from differences between solvent extracts of arabica coffee leaves (Coffea arabica L.).

Method: The extraction method used was maceration with solvents: $70 \%$ ethanol, $96 \%$ ethanol and methanol. Determination of phenol content was carried out using the Folin ciocalteu method. Determination of flavonoid content was done by the $\mathrm{AICl} 3$ method. SPF value is based on the Mansur equation from absorbance scanning using UV Spectrophotometry.

Result: The results obtained were the highest phenol and flavonoid content is in the methanolic extract of arabica coffee namely $62.371 \pm 0.47 \mathrm{mgGAE} / \mathrm{g}$ and $8.6707 \pm 0.04 \mathrm{mgQE} / \mathrm{g}$. In the SPF test, the highest value was obtained from $70 \%$ ethanol extract of $5.0593 \pm 1.28$ at $100 \mathrm{ppm}$ extract concentration with intermediate protection category.
\end{abstract}

Conclusion: Arabica coffee leaves have the potential as an active ingredient in herbal sunscreens

Keywords: Arabica Coffee, Leaves, Phenol, Flavonoid, Sunscreen.

\section{BACKGROUD}

The use of sunscreen has become a necessity of society in recent years due to solar radiation and other problems. Sunlight contains harmful UV rays UV-A (320-400 nm), UV-B (290-320 nm) and UV-C (200-290 $\mathrm{nm}$ ) which cause side effects. UVA and UVB are mainly responsible for skin pathologies including skin pathologies such as sunburn, skin degeneration, rashes, premature aging, allergies and skin cancer. Free radicals or Reactive Oxygen Species (ROS) are induced by UV rays which are absorbed by human skin. ROS can trigger the inflammatory process in the skin ${ }^{1}$. Therefore, human skin needs protection from UV rays to reduce the formation of ROS. ROS can be neutralized by antioxidant molecules. Increased awareness by the public of the damaging effects of solar radiation, thereby increasing the need for the use of sunscreen agents 2,3. Synthetic sunscreens are reported to have several harmful effects such as benzophenone sunscreens, camphor derivatives, and cinnamate derivatives ${ }^{4}$. This is one of the reasons that we have to propose some natural agents as a sunscreen which is more safe than synthetic sunscreen.

*Correspondence: sofia.fatmawati@uhamka.ac.id

${ }^{1}$ Faculty Pharmacy and Science, Muhammadiyah Prof Dr Hamka University, Delima 2 Perumnas Klender, East Jakarta, Indonesia

Full list of author information is available at the end of the article 
Coffee leaves contain many chemical compounds that are beneficial for health. Coffee leaves have antioxidant activity in the range $69.63 \%-70.63 \%$, high total phenol $10.01 \%-11.53 \%$ and caffeine content which is quite low compared to beans ${ }^{5}$. Robusta coffee leaves reported contain saponins, flavonoids, and polyphenols ${ }^{6}$. Coffee leaves also have a good antioxidant capacity because of the phytochemical ingredients from the leaves ${ }^{7,8}$.

Arabica coffee leaves also have a good antioxidant activity against DPPH compared to other species 9,10. The methanolic extract of older Arabica coffee leaves provides total phenolic content and antioxidant activity that is not much different from that of older Robusta coffee leaves ${ }^{11}$. The young coffee leaves exposed to drying processes had the highest total phenolic content, total procyanidins, and DPPH radical scavenging activity ${ }^{12}$.

High antioxidants may offer a high ability to prevent UV rays from penetrating the skin. The use of antioxidants in sunscreen preparations can increase photoprotective activity, the use of substances that are antioxidants can prevent various diseases caused by UV radiation ${ }^{13}$. Ethyl acetate extract and fraction Robusta coffee leaves are reported to have good potential sun protection factor ${ }^{14}$. According to phytochemical constituents and their activity, coffee leaf extract has potential as the new alternative ingredient for cosmetics or cosmeceutical products ${ }^{15}$. However, Arabica coffee leaves have not reported research on its potential as a sun protection factor. The aim of this study was to determine total phenolic content, total flavonoid content and in vitro Sun Protection Factor from Coffee leaves extract.

\section{METHODS}

\section{Extract Preparation}

Arabica coffee leaves that collected from Institut Pertanian Bogor (IPB) were extracted by maceration method using 3 different solvents, $70 \%$ ethanol, $96 \%$ ethanol and methanol. Total simplicia powder used 600 grams in each solvent was put into 3 containers each with 200 grams powder in a container and then extracted with the solvent used 70\% ethanol, 96\% ethanol and methanol in a ratio of 1:10 w/v ${ }^{16}$ The extract was filtered with filter paper and flannel cloth then the extract was concentrated using a rotary evaporator at a temperature of $40^{\circ} \mathrm{C}-45^{\circ} \mathrm{C}$.

\section{Phytochemical Screening}

The phytochemical compounds of coffee leaves extract, such as phenolic, flavonoid, tannin, alkaloid, terpene was qualitatively identified following standard procedures described in the Harbone (1987) ${ }^{17}$ and Indonesian Herb Pharmacopoeia ${ }^{16}$.

\section{Total Phenolic Content}

Gallic acid solution with concentrations of $9,13,17,21,25,29,33$ ppm in distilled water, $1 \mathrm{ml}$ of each solution was pipetted into a tube, then $5 \mathrm{ml}$ of $10 \%$ Folin-Ciocalteau reagent was added (which had been dissolved in distilled water). The solution was to stand for 8 minutes and then add $4 \mathrm{~mL}$ of $7.5 \% \mathrm{Na} 2 \mathrm{CO} 3$ solution (Siddiqui et al. 2017). It was incubated for 161 minutes according to operating time at room temperature. All solutions were measured for absorbance at a maximum absorbance wavelength of $790 \mathrm{~nm}$, then a calibration curve was made between gallic acid concentration and absorbance.

Determination of phenolic content in coffee leaves extract ${ }^{18}$. Each sample weighed $100 \mathrm{mg}$ then dissolved in $10 \mathrm{ml}$ of distilled water until a concentration of $10,000 \mathrm{ppm}$ was obtained. From a concentration of $10,000 \mathrm{ppm}$ in a pipette $0.5 \mathrm{ml}$ in $10 \mathrm{ml}$ of distilled water $(500 \mathrm{ppm})$ then added $1 \mathrm{ml}$ in a pipette $5 \mathrm{ml}$ of Folin Ciocalteu was incubated for 8 minutes, then added $4 \mathrm{~mL}$ of $7.5 \% \mathrm{Na}_{2} \mathrm{CO}_{3}$ and allowed to stand again at operating time 161 at room temperature. The absorbance of the extract solution was measured by UV-Vis spectrophotometer at a maximum absorbance wavelength of $790 \mathrm{~nm}$. Perform 3 repetitions so that the phenol content obtained is obtained as $\mathrm{mgGAE} / \mathrm{g}$ extract. The total phenolic content was calculated using the formula: 
$\mathrm{C}=\frac{C 1 \cdot V \cdot F P}{m}$

$\mathrm{C}=$ Total phenolic content (mg GAE/gram extract)

$\mathrm{C} 1=$ Concentration determined from gallic acid calibration curve $(\mathrm{mg} / \mathrm{ml})$

$\mathrm{V}=$ Extract volume $(\mathrm{ml})$

$\mathrm{M}=$ Mass of weighed extract $(\mathrm{g})$

Total Flavonoid Content

From 1000 ppm quercetin, several concentrations were made, namely 25, 37, 49, 61, 73, 85 and $97 \mathrm{ppm}$. A total of $0.5 \mathrm{ml}$ of quercetin solution was made with several concentrations of pipette then added with $1.5 \mathrm{ml}$ of methanol and added $0.1 \mathrm{ml}$ of $10 \% \mathrm{AlCl}_{3}$ reagent $0.1 \mathrm{ml}$ of sodium acetate $(1 \mathrm{M})$ and $2.8 \mathrm{ml}$ of distilled water. Then the solution was shaken and left for an operating time of 60 minutes at room temperature. Measure the absorbance at a wavelength of $434 \mathrm{~nm}$ against the standard. Each concentration of $0.5 \mathrm{ml}$ of the test solution was added with $1.5 \mathrm{ml}$ of methanol and added $0.1 \mathrm{ml}$ of $10 \% \mathrm{AlCl}_{3}$ reagent $0.1 \mathrm{ml}$ of sodium acetate $(1 \mathrm{M})$ and $2.8 \mathrm{ml}$ of distilled water, then allowed to react during the operating time at room temperature. Measure the absorption at the maximum wavelength against the standard ${ }^{19}$.

\section{Sun Protection Factor Test}

The SPF test was carried out using the spectrophotometric method to determine the SPF value of the extract. The test was carried out on the extract by weighing $100 \mathrm{mg}$ of arabica coffee leaf extract transferred to a $100 \mathrm{ml}$ volumetric flask and then marking the boundary with the solvent. Made with various concentrations of $50 \mathrm{ppm}, 100 \mathrm{ppm}, 150 \mathrm{ppm}$ with each solvent. Then read the absorption at a wavelength of $290 \mathrm{~nm}$ to 320 $\mathrm{nm}$ for every $5 \mathrm{~nm}$ increase using UV-Vis spectrophotometry ${ }^{14}$. The SPF (Sun Protection Factor) value is determined using the equation ${ }^{20}$ :

Information:

$$
\mathrm{SPF}=\mathrm{CF} \times \sum_{7.90}^{320} \quad E E(\lambda) x I(\lambda) x A b s(\lambda)
$$

$\mathrm{CF}=$ Correlation factor (10),

$\mathrm{EE}=$ radiation erythema efficiency with wavelength,

$\mathrm{I}=$ spectrum of light intensity,

Abs $=$ absorbance of sunscreen sample.

The value of EE $\mathrm{x} I$ is a constant that has been determined according to (Sayre et.al., 1979) ${ }^{21}$ in Table 2.

Table 1. Value of EE x I ${ }^{21}$

\begin{tabular}{ll}
\hline Wavelength $(\lambda \mathrm{nm})$ & EE x I \\
\hline 290 & 0,0150 \\
295 & 0,0817 \\
300 & 0,2874 \\
305 & 0,3278 \\
310 & 0,1864 \\
315 & 0,0839 \\
320 & 0,0180 \\
Total & 1,000 \\
\hline
\end{tabular}

\section{RESULTS}

The results obtained in the form of thick extract of arabica coffee leaves. Yield calculations were carried out by calculating the weight of the dry extract obtained against the weight of dry powder before extraction and then multiplied by $100 \%{ }^{16}$ (Table 2 ). 
Table 2. Present yield of Arabica Coffee Leaves Extract

\begin{tabular}{lccc}
\hline Solvents & $\begin{array}{c}\text { Simplisia Powder Weight } \\
\text { (gram) }\end{array}$ & $\begin{array}{c}\text { Extract weight } \\
\text { (gram) }\end{array}$ & Yields (\%) \\
\hline Etanol 70\% & $600.0095 \mathrm{~g}$ & $91.8634 \mathrm{~g}$ & $15.3103 \%$ \\
Metanol & $600.0187 \mathrm{~g}$ & $92.7050 \mathrm{~g}$ & $15.4504 \%$ \\
Etanol 96\% & $600.0368 \mathrm{~g}$ & $52.0928 \mathrm{~g}$ & $10.0148 \%$ \\
\hline
\end{tabular}

The characteristics of the extracts carried out included organoleptic tests (shape, smell, taste and color). The characteristics of the viscous extract of $70 \%$ ethanol, $96 \%$ ethanol extract and methanol extract were carried out to test the characteristics and identification of the viscous extract. Based on the organoleptic test results, 70\% ethanol viscous extract, 96\% ethanol extract and Arabica coffee leaf methanol extract had a greenblack color, weak characteristic odor and bitter taste. The organoleptic parameters of the extract aim to provide an initial introduction to simplicia and extracts using the five senses by describing the shape, color, smell and taste 16 (Table 3 ).

Table 3. Organoleptic Test Extract

\begin{tabular}{lllll}
\hline Material & Smell & Colour & Shape & Taste \\
\hline Simplisa powder & Aromatic & Yellowish Brown & Powder & No taste \\
$70 \%$ Ethanolic Extract & Aromatic & Brownish Black & Thick extract & Bitter taste \\
$96 \%$ Ethanolic Extract & Aromatic & Brownish Black & Thick extract & Bitter taste \\
Methanolic extract & Aromatic & Brownish Black & Thick extract & Bitter taste \\
\hline
\end{tabular}

Phytochemical Screening Test was conducted to qualitatively determine the metabolite compounds present in the extract. The tests carried out included: phenol, alkaloids, flavonoids, tannins, saponins, terpenoids, steroid tests. The results of Arabica coffee extract screening on $70 \%$ ethanol extract, $96 \%$ ethanol and Arabica coffee leaf methanol extract, as shown in table 4. From the results obtained, it was concluded that arabica coffee leaf extract contains phenolic compounds, flavonoids, alkaloids, tannins, and saponins.

Table 4. Phytochemical Screening of Extract

\begin{tabular}{llllcc}
\hline No & $\begin{array}{c}\text { Identificat } \\
\text { ion }\end{array}$ & \multicolumn{1}{c}{ Reagents } & $\begin{array}{c}\text { Ethanol } \\
\mathbf{7 0 \%}\end{array}$ & $\begin{array}{c}\text { Ethanol } \\
\mathbf{9 6 \%}\end{array}$ & $\begin{array}{c}\text { metha } \\
\text { nol }\end{array}$ \\
\hline 1 & Phenol & $\mathrm{FeCl}_{310 \%}$ & $(+)$ & $(+)$ & $(+)$ \\
2 & Alkaloid & Mayer & $(+)$ & $(+)$ & $(+)$ \\
& & Dragendorff & $(+)$ & $(+)$ & $(+)$ \\
& & Bouchardat & $(+)$ & $(+)$ & $(+)$ \\
& & Wagner & $(+)$ & $(+)$ & $(+)$ \\
3 & Flavonoid & $\mathrm{Mg}+\mathrm{HCl}$ & $(+)$ & $(+)$ & $(+)$ \\
4 & Tannin & Gelatin10\% & $(+)$ & $(+)$ & $(+)$ \\
5 & Saponin & Aquadest $\mathrm{HCl}$ & $(+)$ & $(+)$ & $(+)$ \\
6 & Steroid & Aether+Acetic Acid & $(-)$ & $(-)$ & $(-)$ \\
& & Glacial+ $\mathrm{H}_{2} \mathrm{SO}_{4}$ & & & \\
7 & Triterpeno & $\mathrm{CHCl}{ }_{3}+\mathrm{H}_{2} \mathrm{SO}_{4}$ & $(+)$ & $(+)$ & $(+)$ \\
& id & $(\mathrm{P})$ & & & \\
\hline
\end{tabular}




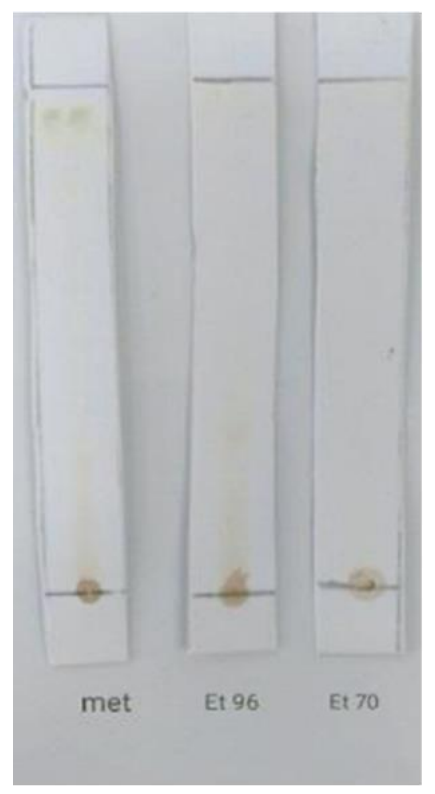

A

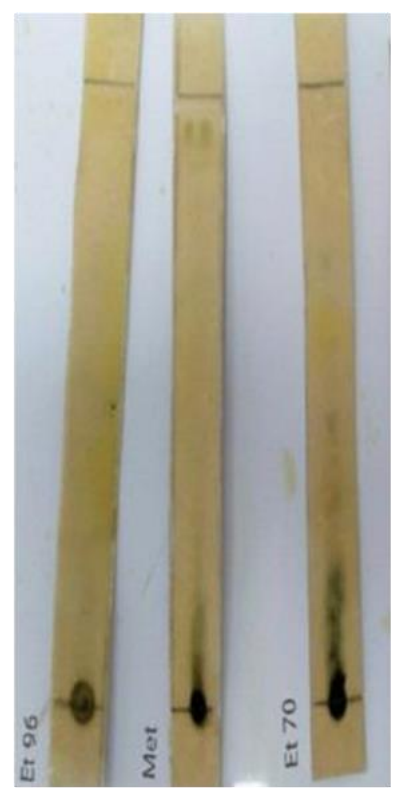

$\mathrm{B}$

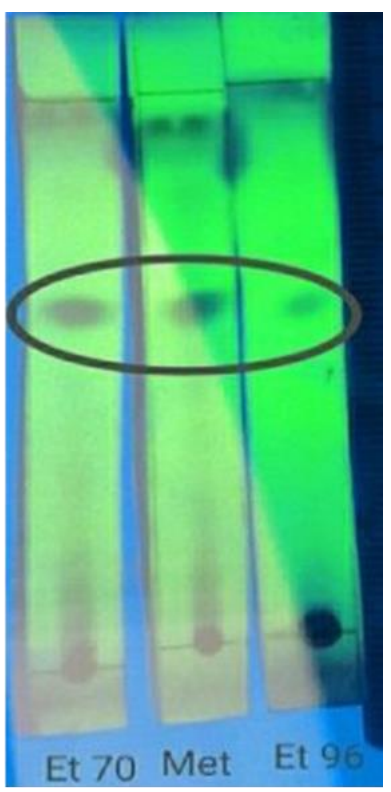

$\mathrm{C}$

Figure 1. Chromatogram of phenolic compound in coffee leaves extract [A] Silica Plate (left to right : methanolic, 96\% ethanolic, 70\% ethanolic extract) [B] slica plate after $\mathrm{FeCl} 3$ sprayed (left to right : $96 \%$ ethanolic, methanolic, 70\% ethanolic extract) (C) silica plate under UV $254 \mathrm{~nm}$ (left to right : 70\% ethanolic, methanolic, $96 \%$ ethanolic extract)

In the identification test of phenolic compounds using TLC (Thin Layer Chromatography) was carried out to identify qualitatively to ensure that the extract contained phenolic compounds. Silica Gel GF254 was used as the stationary phase and chloroform: ethyl acetate: formic acid (5:4:1) was used as the mobile phase22. TLC results showed blue-black spots at UV light $254 \mathrm{~nm}$ but at UV $366 \mathrm{~nm}$ no spots were found. After that, the plate was sprayed using $\mathrm{FeCl} 3$ which was used to detect phenol group compounds.

Gallic acid is used as the standard solution for this test. The maximum wavelength obtained is $790 \mathrm{~nm}$ with an absorbance of 0.578 . The maximum wavelength will be used to measure the absorbance of arabica coffee leaf extract. After getting maximum wavelength, the operating time is carried out to determine the perfect and stable reaction time. The results obtained are at a time of 161 minutes. From the standard curve equation, the linear regression equation is obtained, namely $y=0.0199 x+0.0739$ with a coefficient of $r$ of 0.9999 (Table 5). The linear value shows the correlation between the concentration and the resulting absorbance. The value of $r$ which is getting closer to the value of one proves that the regression equation is linear and a small standard deviation indicates high accuracy ${ }^{11}$. 
Table 5. Result of Total Phenolic Content and Total Flavonoid Content from Arabica Coffee Leaves Extract

\begin{tabular}{|c|c|c|c|c|}
\hline Sample & TPC (mgGAE/gram) & Average TPC & $\begin{array}{l}\text { TFC } \\
\text { (mgQE/gram) }\end{array}$ & Average TFC \\
\hline \multirow{3}{*}{$\begin{array}{l}70 \% \\
\text { extract }\end{array}$} & 53.2637 & $54.7580 \pm 1,72$ & 8.568 & $8.5340 \pm 0.04$ \\
\hline & 55.3065 & & 8.549 & \\
\hline & 55.7059 & & 8.485 & \\
\hline \multirow{3}{*}{$\begin{array}{l}96 \% \\
\text { extract }\end{array}$} & 21.8875 & $22.6907 \pm 0.46$ & 6.150 & $6.1453 \pm 0.04$ \\
\hline & 22.7034 & & 6.095 & \\
\hline & 22.6907 & & 6.191 & \\
\hline \multirow[t]{3}{*}{ Methanolic extract } & 62.0367 & $62.371 \pm 0.47$ & 8.667 & $8.6707 \pm 0.04$ \\
\hline & 62.157 & & 8.716 & \\
\hline & 62.9193 & & 8.629 & \\
\hline
\end{tabular}

Determination of the SPF value for the extract was carried out by measuring the absorbance in the wavelength range of $290-320 \mathrm{~nm}$, with an interval of 5 . The wavelength of $290-320 \mathrm{~nm}$ is the wavelength of UV-B light. nm. The absorbance value decreases and is lowest at a wavelength of $320 \mathrm{~nm}$. Then the absorbance results obtained are calculated by the Mansur equation in equation 2. The SPF value for Arabica coffee leaf extract $70 \%$ ethanol extract, $96 \%$ ethanol extract and methanol extract can be seen in table 6 .

Tabel 6. SPF Value of Coffee Leaves Extract

\begin{tabular}{cccc}
\hline Sample & $\begin{array}{c}\text { Concentration } \\
\text { of Solution } \\
\text { Test }\end{array}$ & SPF Value & $\begin{array}{c}\text { Protection } \\
\text { type }\end{array}$ \\
\hline $70 \%$ Ethanolic Extract & $50 \mathrm{ppm}$ & $4,0571 \pm 0,01$ & Intermediate \\
& $100 \mathrm{ppm}$ & $5,0286 \pm 1,24$ & Intermediate \\
$96 \%$ Ethanolic Extract & $150 \mathrm{ppm}$ & $5,0593 \pm 1,28$ & Intermediate \\
& $50 \mathrm{ppm}$ & $2,3763 \pm 0,70$ & Minimum \\
Methanolic Extract & $100 \mathrm{ppm}$ & $2,4436 \pm 0,73$ & Minimum \\
& $150 \mathrm{ppm}$ & $2,6219 \pm 0,80$ & Minimum \\
& $50 \mathrm{ppm}$ & $3,3106 \pm 0,61$ & Minimum \\
& $100 \mathrm{ppm}$ & $3,1802 \pm 0,01$ & Minimum \\
& $150 \mathrm{ppm}$ & $3,2712 \pm 0,47$ & Minimum \\
\hline
\end{tabular}

\section{DISCUSSION}

Based on the phytochemical screening results of arabica coffee leaves extract in table 7, it was found that the phenol test on all extracts was positive with a color change from dark green to black after reaction with $\mathrm{FeCl} 3$ reagent. The phenol compounds will reduce $\mathrm{Fe}^{3+}$ to $\mathrm{Fe}^{2+}$ so as a blackish green color is produced. In the identification of flavonoids, Arabica coffee leaves extract was positive for flavonoid compounds with a typical change in color from yellow to orange. This is due to the reduction reaction in $\mathrm{Mg}$ after the addition of $\mathrm{HCl}$, the reaction gives a reddish yellow color ${ }^{23}$.

Alkaloids were tested using 4 reagents, namely Mayer, Dragendorff, Bouchardat and Wagner. The $62 \mid \mathrm{P}$ a g e 
Mayer test showed a positive result of $70 \%$ ethanol and the methanol extract was characterized by the formation of a yellowish white precipitate. In Dragendorff's reagent the positive extract contains alkaloid compounds which are indicated by the presence of orange precipitation, because the nitrogen compounds in the alkaloids form covalent bonds with metal ions $\mathrm{K}+$ from potassium tetraiodobismuthate to form potassiumalkaloid complexes. In the test results with Bouchardat reagent produced a brown precipitate. The reaction occurs because of the bond between metal ions $\mathrm{K}+$ from potassium iodide (KI) with nitrogen compounds in the alkaloids to form a precipitate complex. In the alkaloid test with Wagner's reagent, positive results were obtained on extracts containing alkaloid compounds characterized by a brownish white precipitate. The formation of these deposits is due to nitrogen compounds in the alkaloids reacting with metal ions $\mathrm{K}+$ from potassium tetraiodomercurate (II) to form a potassium-alkaloid complex ${ }^{24}$.

The tannin test showed a yellowish white precipitate. This indicates that the extract contains tannin compounds, because the tannin compounds are able to precipitate proteins. Arabica coffee leaf extract gave positive results on steroid testing. It is characterized by a change in color to reddish brown. The color change was due to the compound's ability to form concentrated $\mathrm{H} 2 \mathrm{SO} 4$ color in acetic anhydride solvent ${ }^{23}$ and showed negative results in the triterpenoid test which formed a blackish brown color. The presence of saponins in the extract was indicated by the formation of foam after shaking the extract dissolved in hot water. The foam produced was as high as $1.4 \mathrm{~cm}$ in each extract, the foam in the test occurred because the saponins had polar and non-polar groups that formed micelles. The micelles are formed causing the polar groups to face out and the non-polar groups to face inwards and this is what looks like foam ${ }^{17}$.

The Rf values obtained from TLC plates for each Arabica coffee leaf extract sequentially at $70 \%$ ethanol extract, $96 \%$ ethanol extract and methanol were; $0.7589 ; 0.7419 ; 0.7741$. The difference in the mobile phase will cause a difference in the propagation distance of the sample, so it will affect the $\mathrm{Rf}$ value. This difference occurs because it is based on the nature of the polarity of the compound ${ }^{25}$.

Based on the research, it was found that the phenolic content of Arabica coffee leaf extract obtained the highest phenolic content in the methanol extract, namely $62.371 \pm 0.47 \mathrm{mgGAE} / \mathrm{g}$ then $70 \%$ ethanol extract $54.7580 \pm 1.72 \mathrm{mgGAE} / \mathrm{g}$ and the lowest phenol content in the $96 \%$ ethanol extract $22.6907 \pm 0.46 \mathrm{mgGAE} / \mathrm{g}$ . The flavonoid content of Arabica coffee leaf extract obtained the highest in the methanol extract, namely $8,6707 \pm 0.04 \mathrm{mgQE} / \mathrm{g}$ then $70 \%$ ethanol extract 8,5340 $\pm 0,04 \mathrm{mgQE} / \mathrm{g}$ and the lowest flavonoid content in the $96 \%$ ethanol extract $6,1453 \pm 0.04 \mathrm{mgQE} / \mathrm{g}$. It is appropriate that polar solvents are able to dissolve phenol better ${ }^{26}$. Based on the dielectric constant, organic solvents can be divided into two, namely polar and nonpolar solvents. The dielectric constant is expressed as the repulsive force between two electrically charged particles in a molecule. The higher the dielectric constant, the more polar the solvent. Methanol has a higher polarity level than $70 \%$ ethanol so that the extract with methanol solvent can attract phenolic compounds better than $70 \%$ ethanol extract and $96 \%$ ethanol. The phenolic and flavonoid content will increase in the extract as the polarity of the solvent increases ${ }^{27}$. Methanol is an effective solvent for extracting antioxidant compounds, a universal solvent so that it can attract most of the polar and nonpolar compounds in the material ${ }^{28}$ can attract phenolic compounds, saponins, tannins and terpenoids in plants ${ }^{29}$. Phenol compounds have the potential as antioxidants that can act well as sunscreens. This is due to the presence of a hydroxyl group that functions as a donor of hydrogen atoms when reacting with radical compounds through an electron transfer mechanism so that the oxidation process is inhibited ${ }^{13}$.

The results of the sunscreen activity of $70 \%$ ethanol extract had an SPF value higher than a concentration of $50 \mathrm{ppm}$ to $150 \mathrm{ppm}$ with intermediate protection or with an SPF value of 4-6 indicating that the extract could withstand or protect the skin against sunlight four times longer without sunburn. Then followed by methanol extract and $96 \%$ ethanol extract from a concentration of $50 \mathrm{ppm}$ to $150 \mathrm{ppm}$ with minimal protection with an SPF value of 2-4 indicating that the extract can withstand or protect the skin against sunlight twice as $63 \mid \mathrm{P}$ a g e 
long without burning skin.

The SPF value showed that with increasing concentration. Its value also increases due to an increase of phenol and flavonoid compounds in the test solution that can absorb ultraviolet radiation. The test results also showed that with different solvents, the given SPF values remained different even though there was an increase in the concentration of the extract with other solvents. This can indicate the different yield and type of a phytochemical compound according to the coffee leaves extraction solvent.

The mechanism of action of sunscreen protection can be explained as compound molecules that absorb energy from UV rays will be excited to a higher energy level, when returning to a lower energy level, will release energy. Meanwhile, UV rays that are absorbed by molecules that have the potential as sunscreens will have lower energy, so they can reduce the negative impact of UV exposure. With this mechanism, phenolic compounds and compounds that act as sunscreens have the potential for photoprotection ${ }^{14}$.

From these results, it can be correlated with the measured phenol content of each extract with sunscreen activity. The presence of sunscreen protection activity in Arabica coffee leaf extract is due to plant chemical compounds that have the potential to absorb UV, one of which is phenol. The highest phenolic content were found in methanol extract, $70 \%$ ethanol extract and 96\% ethanol extract, respectively. Meanwhile, in the sunscreen activity test, the highest SPF values were obtained from $70 \%$ ethanol extract, methanol and $96 \%$ ethanol, respectively. These results can occur because compounds that have the potential as sunscreens are not only phenolic but also many other compounds such as flavonoids, tannins, vitamins ${ }^{30,31}$.

Although the chemical screening of all positive extracts contained phenolic compounds, flavonoids, tannins, it is possible that the number and types of secondary metabolites of each extract were different so that the results obtained were also different. In addition, the yield data obtained has to do with secondary metabolites from a sample so that if the amount of yield increases, the number of compounds contained in the sample also increases. Compounds with aromatic rings and chromophore groups also have an effect on UV protection ${ }^{32}$.

\section{CONCLUSION}

From the research conducted, it can be concluded that the difference in solvent can affect the phenol and flavonoid content based on the level of polarity of the solvent. The highest yield of phenol and flavonoid content in arabica coffee leaves extract was obtained from methanol, 70\% ethanol and $96 \%$ ethanol extract. Meanwhile, in the SPF test, the highest SPF values were obtained respectively from $70 \%$ ethanol extract with moderate protection category, methanol and $96 \%$ ethanol with minimum protection category.

\section{ACKNOWLEDGEMENT}

Lemlitbang Muhammadiyah Prof Dr Hamka University for funding this research.

\section{CONFLICT OF INTEREST}

We declare that we have no conflict of interest regarding the publication of this article.

\section{AUTHORS' CONTRIBUTION}

SF, analyzed and interpreted the TPC, TFC and SPF data of the extract leaves. LRS and FN monitored the extract preparation, NP performed the TPC and SPF examination of the extract, and K performed the TFC examination of the extract, All authors read and approved the final manuscript. 


\section{FUNDING}

Lemlitbang Muhammadiyah Prof Dr Hamka University

\section{AUTHOR DETAILS}

${ }^{1}$ Faculty Pharmacy and Science, Muhammadiyah Prof Dr Hamka University, Delima 2 Perumnas Klender, East Jakarta, Indonesia

\section{REFERENCES}

1. Pillai S, Oresajo C, Hayward J. Ultraviolet radiation and skin aging: Roles of reactive oxygen species, inflammation and protease activation, and strategies for prevention of inflammation-induced matrix degradation - A review. Int J Cosmet Sci. 2005;27(1):17-34. doi:10.1111/j.1467-2494.2004.00241.x

2. Afaq F, Mukhtar H. Photochemoprevention by botanical antioxidants. Skin Pharmacol Appl Skin Physiol. 2002;15(5):297-306. doi:10.1159/000064533

3. Clydesdale GJ, Dandie GW, Muller HK. Ultraviolet light induced injury: Immunological and inflammatory effects. Immunol Cell Biol. 2001;79(6):547-568. doi:10.1046/j.1440-1711.2001.01047.x

4. Paul SP. Ensuring the Safety of Sunscreens, and Their Efficacy in Preventing Skin Cancers: Challenges and Controversies for Clinicians, Formulators, and Regulators. Front Med. 2019;6(September):1-7. doi:10.3389/fmed.2019.00195

5. Khotimah K. Karakteristik Kimia Kopi Kawa Dari Berbagai Umur Helai Daun Kopi Yang Diproses Dengan Metode Berbeda. J Teknol Pertan. 2014;9(1):40-48.

6. Patay ÉB, Bencsik T, Papp N. Phytochemical overview and medicinal importance of Coffea species from the past until now. Asian Pac J Trop Med. 2016;9(12):1127-1135. doi:10.1016/j.apjtm.2016.11.008

7. Rahmah Nasution M, Br Manullang M. Aktivitas Antioksidan Seduhan Daun Kopi Kawa Kering (Coffea arabica L) dengan Metode DPPH. J Insa Farm Indones. 2020;3(1):114-123. doi:10.36387/jifi.v3i1.467

8. Acidri R, Sawai Y, Sugimoto Y, et al. Phytochemical profile and antioxidant capacity of coffee plant organs compared to green and roasted coffee beans. Antioxidants. 2020;9(2):1-18. doi:10.3390/antiox9020093

9. Ristiana D. Aktivitas Antioksidan Dan Kadar Fenol Berbagai Ekstrak Daun Kopi (Coffea Sp.): Potensi Aplikasi Bahan Alami Untuk Fortifikasi Pangan. J Apl Teknol Pangan. 2017;6(2):89-92. doi:10.17728/jatp.205

10. Hasanah M, Hilma H, Puguh S. antioxidant Activity of Extract and Fractions from Coffee arabica L Leaves by DPPH Radical Scavenging Method. Sci J PPI-UKM Sci Eng. 2016;3(4):162-165. doi:10.21752/sjppi-ukm/se/a14092016

11. Kristiningrum N, Cahyanti YN, Wulandari L, Farmasi F, Jember U. Determination of Total Phenolic Content and Antioxidant Activity in Methanolic Extract of Robusta and Arabica Coffee Leaves. In: ICMHS 2016. ; 2016:96-99.

12. Ngamsuk S, Huang TC, Hsu JL. Determination of phenolic compounds, procyanidins, and antioxidant activity in processed coffea Arabica L. leaves. Foods. 2019;8(9):1-13. doi:10.3390/foods8090389

13. Ebrahimzadeh MA, Enayatifard R, Khalili M, Ghaffarloo M, Saeedi M, Charati JY. Correlation between sun protection factor and antioxidant activity, phenol and flavonoid contents of some medicinal plants. Iran J Pharm Res. 2014;13(3):1041-1048. doi:10.22037/ijpr.2014.1554

14. Yuliawati KM, Sadiyah ER, Solehati R, Elgiawan A. Sunscreen Activity Testing Of Robusta Coffee (Coffea cenephora ex Froehner) Leave Extract and Fractions. IJPT Indones J Pharm Sci Technol. 2019;1(1):24-29.

15. Kiattisin K, Nitthikan N, Poomanee W, Leelapornpisid P, Viernstein H, Mueller M. Anti-inflammatory, antioxidant activities and safety of coffea arabica leaf extract for alternative cosmetic ingredient. Chiang Mai J Sci. 2019;46(2):284-294.

16. Indonesian Ministry of Health. Farmakope Herbal Indonesia.; 2017.

17. Harbone J. Metode Fitokimia. Second. ITB Press; 1987.

18. Siddiqui N, Rauf A, Latif A, Mahmood Z. Spectrophotometric determination of the total phenolic content, 
spectral and fluorescence study of the herbal Unani drug Gul-e-Zoofa (Nepeta bracteata Benth). $J$ Taibah Univ Med Sci. 2017;12(4):360-363. doi:10.1016/j.jtumed.2016.11.006

19. Hikmawanti NPE, Fatmawati S, Arifin Z, . V. Pengaruh Variasi Metode Ekstraksi Terhadap Perolehan Senyawa Antioksidan Pada Daun Katuk (Sauropus androgynus (L.) Merr). J Farm Udayana. 2021;10(1):1. doi:10.24843/jfu.2021.v10.i01.p01

20. Mansur JDS BM. Determinação do fator de proteção solar por espectrofotometria. An Bras Dermatol. 1986;61:121-124.

21. Sayre RM, Agin PP, LeVee GJ, Marlowe E. A Comparison of In Vivo and In Vitro Testing of Sunscreening Formulas. Photochem Photobiol. 1979;29(3):559-566. doi:https://doi.org/10.1111/j.17511097.1979.tb07090.x

22. Ihsan P, Rahmani PA, Shalas AF. Validasi Metode KLT-Densitometri untuk Analisis Kuersetin dalam Ekstrak dan Produk Jamu yang Mengandung Daun Jambu Biji (Psidium guajava L.). Pharm J Indones. 2019;5(1):45-51.

23. Fajriaty I, I H H, Setyaningrum R. Skrining Fitokimia Lapis Titpis Dari Ekstrak Etanol Daun Bintangur ( Calophyllum soulattri Burm . F .). J Pendidik Inform dan Sains. 2018;7(1):54-67.

24. Parbuntari H, Prestica Y, Gunawan R, Nurman MN, Adella F. Preliminary Phytochemical Screening (Qualitative Analysis) of Cacao Leaves (Theobroma cacao L.). EKSAKTA Berk Ilm Bid MIPA. 2018;19(2):40-45. doi:10.24036/eksakta/vol19-iss2/142

25. Kagan IA, Flythe MD. Thin-layer chromatographic (TLC) separations and bioassays of plant extracts to identify antimicrobial compounds. J Vis Exp. 2014;(85):51411. doi:10.3791/51411

26. Moein S, Moein MR. Relationship between antioxidant properties and phenolics in Zhumeria majdae. $J$ Med Plants Res. 2010;4(7):517-521. doi:10.5897/JMPR10.292

27. Ganesan P, Kumar CS, Bhaskar N. Antioxidant properties of methanol extract and its solvent fractions obtained from selected Indian red seaweeds. Bioresour Technol. 2008;99(8):2717-2723. doi:10.1016/j.biortech.2007.07.005

28. Salamah N, Widyasari E. Aktivitas Antioksidan Ekstrak Metanol Daun Kelengkeng (Euphoria longan (L) Steud.) dengan Metode Penangkapan Radikal 2,2'-difenil-1-pikrilhidrazil. Pharmaciana. 2015;5(1):2534. doi:10.12928/pharmaciana.v5i1.2283

29. Astarina NWG, Astuti KW, Warditiani NK. Skrining Fitokimia Ekstrak Metanol Rimpang Bangle (. $J$ Farm Udayana. 2012;344(4):1-7.

30. Donglikar MM, Deore SL. Development and evaluation of herbal sunscreen. Pharmacogn J. 2017;9(1):83-97. doi:10.5530/pj.2017.1.15

31. Malsawmtluangi C, Nath DK, Jamatia I, Lianhimgthangi EZ, Pachuau L. Determination of Sun Protection Factor (SPF) number of some aqueous herbal extracts. J Appl Pharm Sci. 2013;3(9):150-151. doi:10.7324/JAPS.2013.3925

32. Geoffrey K, Mwangi AN, Maru SM. Sunscreen products: Rationale for use, formulation development and regulatory considerations. Saudi Pharm J. 2019;27(7):1009-1018. doi:10.1016/j.jsps.2019.08.003 